the State did not contribute either to capital or to income expenditure. Thirdly, British universities are now co-educational, and the one imperative condition imposed on them is that unqualified persons should not be let loose on the community. Fourthly, the universities, if not the sole, are the main avenues to the professions and to all branches of teaching. They are second to none in the range and quality of their studies, equipment and teaching, and the demand for strengthening every form of research comes primarily from the universities, because their staffs know what can and ought to be done, and enlighten the community by doing it. Finally, after emphasizing that the freedom and independence of British universities are a sure guarantee of their capacity to meet the needs of the future, Sir Charles insists that, in accordance with the medieval ideal, a university is not a real university unless its members pray together, work together and play together.

\section{New Film-Strip Projector}

IN the field of education, the post-war period is likely to be characterized by a marked increase in the use of visual aids. The ordinary lantern will most probably be replaced, except for large audiences, by the film-strip projector. The advantages of this newer form of projector are many and do not require elaboration. Further, it is likely that the film-strip projector will be used for educational purposes in conjunction with a sub-standard cinematograph projector; for, to-day, the complete visual unit comprises a film together with film-strips, charts, etc. Although a few associations have concerned themselves with visual education during recent years, progress has not been possible because of the lack of projectors for films and film-strips. To-day, the outlook is brighter, and Messrs. Dufay-Chromex, Ltd., 14 Cockspur Street, London, S.W.1, announce that they will have a new film-strip projector on the market in the near future. It is of attractive design and incorporates many new ideas which have been developed while the machine has been in use with various Service Departments. Several features are worthy of special mention. The gate is modelled on that of a cinematograph projector, and traction of the strip is effected by a lever which, with a single movement, advances the strip one frame. The gate is adaptable for three sizes of frame which are in common use. The optical unit merely slides in the lamp house, thus permitting the easy replacement of a projection lamp. The film is kept flat in the gate by a glass plate, the pressure on which is removed as the film is passed through.

\section{Earthquakes During the First Quarter of 1945}

DURING the first quarter of 1945 , fourteen earthquakes were registered by the seismographs at King's College Observatory, Aberdeen, and Dr. A. E. M. Geddes reports that the instruments were not working during March 7-21. The largest shock was on Feb. ruary 10, registered at Aberdeen at $05 \mathrm{~h} .9 \mathrm{~m} .48 \mathrm{~s}$. G.M.T. from an epicentre estimated distant $77.4^{\circ}$, and developed a maximum ground amplitude on the east component at Aberdeen of $178 \mu$ at $05 \mathrm{~h} .36 \mathrm{~m}$. $11 \mathrm{~s}$. G.M.T. At the Dominion Observatory at Wellington, Now Zealand, six strong earthquakes were registered during February and five during March. The earthquake on February 26, with epicentre about 77 from Wellington, was a deep-focus shock, the focus being 180-200 km. below the surface of the earth. The earthquake of March 18 had its epicentre south of the Kermedecs, only about $7 \mathrm{~km}$. distant from Auckland, New Zealand. The greatest felt earthquake in New Zealand during February occurred on the 18th and was felt in north-west Nelson with intensity on the modified Mercalli scale of 4 . During March fifteen earthquakes were felt in New Zealand, the greatest intensity being scale 4 at New Plymouth on March 11, in the northern part of South Island and the Cook Strait region on March 12, at Wairoaton on March 19 and at Masterton on March 19 (separate shock).

During March, twelve earthquakes and tremors were registered by the seismographs at the geophysical observatory at Toledo, Spain. The strongest of these was on March 18 ; $i P z$ registered at $00 \mathrm{~h} .09 \mathrm{~m}$. 33s. G.M.T. from an epicentre some $76^{\circ}$ distant, and a ground amplitude of $35 \mu$ was attained at Toledo at 00h. 33m. 21s. G.M.T. The United States Coast and Geodetic Survey, in co-operation with Science Service and the Jesuit Seismological Association, has determined the provisional epicentre of the earthquake of March 17, using reports from ten seismographic observatories, to be at lat. $6 \cdot 9^{\circ} \mathrm{N}$., long. $78 \cdot 0^{\circ} \mathrm{W}$., which is off Colombia.

\section{Announcements}

THE centenary celebrations of the Imperial College of Science and Technology, London, will take place during October 25-27. The opening meeting will be held in the Albert Hall, and will be attended by the King, as visitor of the College, who will be accom. penied by the Queen.

THE fifth series of postgraduate lectures arranged by the London Section of the Oil and Colour Chemists' Association will be delivered by Prof. E. N. da C. Andrade, who will speak on "Viscosity and Plasticity". The lectures will be given at the Royal Institution, Albemarle Street, London, on October 11, 18 and 25 , at 6.30 p.m. Admission will be by ticket only (price 1Cs.), applications for which must be sent to David E. Roe, c/o Atlas Preservative Co., Ltd., Fraser Road, Erith, Kent.

THE following appointments in the Colonial Services have been made: J. McA. Todd, to be plant pathologist, Gold Coast; R. E. T. Hobbs, agricultural officer, Kenya, to be senior agricultural officer, Kenya; A. C. Maher, agricultural officer, Kenya, to be senior soil conservation officer, Kenya; $\mathrm{O}$. S. Swainson, principal agricultural officer, Nigeria, to be senior agricultural officer, Zanzibar; T. Y. Watson, agricultural officer, Kenya, to be senior agricultural officer, Kenya; I. R. Dale, assistant conservator of forests, Uganda, to be senior assist. ant conservator of forests, Uganda; A. Foggie, assistant conservator of forests, Nigeria, to be senior assistant conservator of forests, Nigeria; J. C. Rammell, senior assistant conservator of forests, Kenya, to be conservator of forests, Kenya.

The Museum Book Store, Ltd., 45, Museum Street, London, W.C.1, state that they have acquired the library of the late Prof. Hans Sachs (see Nature, May 19). The collection includes long runs of the Centralblatt für Bacteriologie, Zeitschrift für Immun. ologie, etc., and some ten thousand reprints in 119 labelled boxes. Particulars will be sent on request. 